\title{
A new QUALIS for the
}

\section{Dental Press Journal of Orthodontics}

\section{David Normando 1}

\begin{abstract}
"The first quality of the commander-in-chief is a cool head to receive a correct impression of things. He should not allow himself to be confused by either good or bad news."
\end{abstract}

Napoleon Bonaparte, French emperor

In the most recent QUALIS, published at the end of 2016, Dental Press Journal of Orthodontics (DPJO) was upgraded from B3 to B2 stratum by the journals evaluation committee of CAPES (Coordination for the Improvement of Higher Education Personnel), a foundation of the Brazilian Ministry of Education (MEC). That was great news to the main orthodontic scientific journal in Latin America.

QUALIS-CAPES is a system used to classify a journal that has published scientific papers from Brazilian postgraduate programs. The classification is divided by evaluation areas, in accordance with predefined criteria, and is periodically updated. Scientific journals are categorized by indicative strata of their quality: A1, the highest one; A2, B1, B2, B3, B4, B5 and C, equivalent to zero. ${ }^{1}$ Each area of knowledge has its specificities and criteria for the journals classification; however, the essence of this system is the impact factor of the journal - an index that measures the average number of citations of papers published in a certain journal.

In June 2016, the data corresponding to the citations from 2015 were published. DPJO, indexed by Scopus on SCImago base, had a cites per doc of 0.44 , a threefold increase in comparison with the previous year. ${ }^{2}$ Its impact on QUALIS-CAPES classification system was DPJO being given a better stratum. When a journal reaches a higher stratum in QUALIS-CAPES, Brazilian researchers start to prioritize it for submission of their studies. It is a ripple effect: more papers, better selection, greater impact of the studies published and, consequently, a better impact factor of the journal.

\footnotetext{
${ }^{1}$ Adjunct professor, Universidade Federal do Pará (UFPA), School of Dentistry, Belém, Pará, Brazil. Coordinator, Universidade Federal do Pará (UFPA), Graduate program in Dentistry, and ABO-Pará, Specialization course in Orthodontics, Belém, Pará, Brazil.
} 
Most of the Brazilian postgraduate programs published scientific papers in Dental Press Journal of Orthodontics between 2013 and 2016. ${ }^{3}$ Therefore, DPJO contributes to the maintenance of professors of all specialties — but mainly Orthodontics - in a wide variety of postgraduate programs. Its growth will allow greater participation of Orthodontics professors in programs that still do not have such discipline, contributing to diversifying Brazilian post-graduation and improving the necessary multidisciplinarity of scientific production, which is so important to boost the impact of Brazilian dental science.

However, QUALIS 2015 has brought some other good news to Brazilian Orthodontics, since many orthodontic journals have grown, what favors, mainly, the professors of this specialty, in the Brazilian post-graduation scenario. While DPJO went from B3 to B2 (the same happened to the Australian Orthodontics Journal), the European Journal of Orthodontics went from B2 to B1. Other journals that were not present in the classification system were included, most of them as B3. Another important fact is that no orthodontic journal has been given a lower stratum in comparison to previous years. These data confirm the growth of Orthodontics' impact factor in the world scientific scenario and of Brazilian Orthodontics in world Orthodontics. ${ }^{4}$

David Normando - editor-in-chief (davidnormando@hotmail.com)
REFERENCES

1. CAPES. Classificação da produção intelectual. 2014 [Acesso em: 10 Jan 2017]. Disponivel em: http://www.capes.gov.br/avaliacao/instrumentos-deapoio/classificacao-da-producao-intelectual

2. Normando D. Science and impact: the challenge faced by Dental Press Journal of Orthodontics. Dental Press J Orthod. 2016 July-Aug:21(4):12-3.

3. Normando D. Dental Press Journal of Orthodontics and QUALIS. Dental Press J Orthod. 2015 Sept-Oct:20(5):12-3.

4. Normando D. The Brazilian orthodontic storm. Dental Press J Orthod. 2016 May-June;21(3):13-4. 